\title{
A STUDY ON FIBER REINFORCED HIGH PERFORMANCE CONCRETE USING MULTIPLE MINERAL ADMIXTURES
}

\author{
H.M.Somasekharaiah ${ }^{1}$, Mahesh Sajjan ${ }^{2}$, Nelson Mandela ${ }^{3}$ \\ ${ }^{1}$ Professor, Department of Civil Engineering, RYMEC Ballari, Karnataka, India, \\ ${ }^{2}$ Assistant Professor, Department of Civil Engineering, RYMEC Ballari, Karnataka, India, \\ ${ }^{3} P G$ Student, Department of Civil Engineering, RYMEC Ballari, Karnataka, India,
}

\begin{abstract}
HPC could be a concrete that has been designed to be additional harder and stronger than typical concrete. HPC mixtures area unit primarily composed of constant materials as typical concrete mixtures. However the proportions area unit designed or designed to supply the strength and sturdiness required for the structural and environmental needs of the project. The main objective of this project is to evaluate the strength \& behavior of HPC, with using of admixtures combinations of steel fibers and polypropylene fibers. This investigation has been made to increase the strength of concrete by adding supplementary binder materials like fly-ash, silica fume, metakaolin along with steel and polypropylene fibers. The cubes, cylinders and beams specimens (moulds) are casted with concrete by using primary ingredients such as cement, water, fine aggregate and course aggregate, apart from this Cement is replaced with $22.5 \%$ of mineral admixtures (i.e. $7.5 \%$ of each Silica fume, Metakaolin and Fly ash) and 37.5\% of mineral admixtures (i.e. 12.5\% of each Silica fume, Metakaolin and Fly ash) further addition of crimped steel fibers with varying percentage of $0 \%$ and $0.5 \%$, along with the polypropylene fibers to $0.25 \%$ are added to enhance tensile and flexural strength. The casted specimens are cured with water for 7 days and 28 days to evaluate the compressive strength, split tensile strength and flexural strength
\end{abstract}

KEYWORDS: Silica Fume, Metakaolin, Fly ash, steel fiber, polypropylene fiber, super plasticizer, strength properties.

\section{INTRODUCTION}

Concrete is a composite material composed of coarse granular material (the aggregate or filler) embedded in a hard matrix of material (the cement or binder) that fills the space between the aggregate particles and glues them together. Concrete could be a construction material most generally employed in the planet. It is employed in many alternative structures adore dam, pavement, building frame, bridges etc. Its worldwide production exceeds that of steel by an element of ten in tariff and by over an element of 30 in volume. It is over 10 times of the consumption by weight of steel. Concrete is common, as a result of Concrete is neither as strong nor as tough as steel. Nominal concrete is meant on the idea of compressive strength and it doesn't meet several practical necessities adore solidity, resistance to frost, thermal cracking adequately. Standard hydraulic cement concrete is found deficient in respect of:

1. Service life is shorter and require maintenance

2. Gain of strength is slower and longer release time of forms

3. Capacity to absorbs the earthquake vibration energy and resists the structures.

4. Repair and retrofitting jobs

High performance concrete (HPC) successfully meets the above requirement.

Concrete is the most significant and integral material widely used all over the world which possesses very strength and adequate workability properties, generally concrete is a mixture of ingredient materials such as hydraulic cement, fine aggregate, water and course aggregate, out of which the cement is the most key constituent in concrete and which acts as a binder in the concrete.

[1] Ch. Kusuma Keerthi, K. Rajasekhar. By replacing the cement by $15 \%$ of fly ash and $5 \%$ of metalaolin, the maximum compressive strength can achieved in M80 grade concrete is up to $89.3 \mathrm{Mpa}$.

[2] Dr. B. Vidivelli , A. Jayaranjini. For M60 grade of concrete the replacement of cement by $15 \%$ of mineral admixtures i.e. $10 \%$ Fly ash and $5 \%$ Silica fume, the compressive strength is $61.5 \mathrm{Mpa}$. The replacement of cement by $15 \%$ of Fly ash and $7.5 \%$ of Silica fume, the split tensile strength is $3.60 \mathrm{Mpa}$. For M70 grade of concrete the replacement of cement by $30 \%$ of mineral admixtures i.e. $20 \%$ Fly ash and $10 \%$ Metakaoli, the compressive strength is $61.5 \mathrm{Mpa}$ and split tensile strength is 5.58Mpa. For M80 grade of concrete the replacement of cement by $20 \%$ Fly ash and $13.23 \%$ Metakaoli, the compressive strength is $88.9 \mathrm{Mpa}$ and split tensile strength is 6.12Mpa. For M90 grade of concrete the replacement of cement by 33\% Fly ash and $15.23 \%$ Metakaoli, the compressive strength is $98.3 \mathrm{Mpa}$ and split tensile strength is $6.10 \mathrm{Mpa}$

[3] Magudeaswaran.P, Eswaramoorthi. P. The investigated project deals with the compressive strength \& split tensile strength for M60 grade concrete by replacing cement with silica fume and fly ash in different replacement levels of cement.

[4] Arfath Khan Md, Abdul Wahab, B. Dean Kumar. In this experimental investigation the cement is replaced by 
condensed Silica fume and Metakaolin with different percentage $0-15 \%$ and steel fiber is $0-1.5 \%$. The highest compressive strength is obtained in a concrete is with $10 \%$ of condensed Silica fume \& $5 \%$ of Metakaolin and $1.5 \%$ of steelfiber.

[5] Brooks J.J. et al. The Silica fume, Fly ash \& Metakaolin retards setting time for high-strength concrete. In general, increasing pozzolan levels increased setting time, however, for $\mathrm{MK}$ this increase was only observed up to a $10 \%$ replacement level.

\section{MATERIALS}

a) Cement (OPC): Ultra tech cement 43 grade was used. Specific Gravity of Cement was 3.08.

b) Coarse aggregate: - crushed granite metal with $60 \%$ passing $20 \mathrm{~mm}$ and retained on $12.5 \mathrm{~mm}$ sieve and $40 \%$ passing $12.5 \mathrm{~mm}$ and retained on $4.75 \mathrm{~mm}$ sieve were used. The weight of coarse aggregate was $60 \%$ of the total aggregate and specific gravity of coarse aggregate was 2.70 .

c) Fine aggregate: - River sand from local sources was used as fine aggregate. Specific Gravity was 2.50.

d) Water: Water used for both mixing and curing should be free from harmful amounts of harmful materials. In the present work drinkable tap water was mixed directly with concrete.

e) Silica Fume: Silica fume is the very fine non crystalline silica. It is produced in electric arc furnace. Silica fume is by-product of the production of elemental silicon or alloys containing silicon.

f) Fly ash: Fly ash obtained from thermal power plant at KUDITHINI BELLARY THERMAL POWER STATION was used in the investigation. The specific gravity is 1.9.

g) Metakaolin is obtained by heating KOALIN (plentiful natural clay mineral) to temperature of $650-900^{\circ} \mathrm{C}$, this treatment serves to break down the kaolin structure. Further surrounded hydroxyl ions are eliminated and resulting disorder with alumina and silica layers which yields a highly reactive amorphous materials with Puzzolanic and latent hydraulic reactivity, which is fitting for use in cementing applications.

h) Super plasticizer: To improve the workability of the mixes, a high range water reducing agent Fosroc conplast SP430 (SNF- Sulphonated Naphthalene Formaldehyde) is used.

i) Steel fibers: Crimped steel fibres of $30 \mathrm{~mm}$ length with a dia of $0.6 \mathrm{~mm}$ and an aspect ratio of 50, density is 7840 $\mathrm{Kg} / \mathrm{m} 3$ and specific gravity is 7.9 were used throughout the experimental program.

f) Polypropylene fibers: RECRON 3S TYPE-CT 2012 polypropylene fibres of density $946 \mathrm{Kg} / \mathrm{m} 3$ are used in experimental program.

\section{METHODOLOGY}

In this project the cement is replaced by mixtures of mineral admixtures such as silica fume, metakaoline and fly ash, in ratio of $0 \%, 22.5 \%(7.5 \%$ of each silica fume, metakaoline and fly ash) and $37.5 \%$ (12.5\% of each silica fume, metakaoline and fly ash) is used in concrete mix. The steel fiber of different dosage i.e. $0 \%$ and $0.5 \%$ and $0.25 \%$ polypropylene fiber with constant is used in concrete mixes. Each different replacement of cement by mineral admixtures (i.e. $0 \%, 22.5 \%$ and $37.5 \%$ ) of concrete mix is done, with different water binder ratio of $0.3 \%, 0.35 \%$ and $0.4 \%$ with super plasticizer of $0.6 \%$ is used. By using cubes (150mmx $150 \mathrm{mmx} 150 \mathrm{~mm})$, cylinders $(150 \mathrm{~mm}$ dia and 300 length) and prism (100mmx100mmx500) the different concrete mixes is caste and tests are conducted to find out the compressive strength, split tensile strength and flexural strength at 7 and 28 days.

Compressive strength: It is observed that the cube compressive strength is increased by $2.29 \%$ than the $0 \%$ of mineral admixtures cube compressive strength. The increased in strength is very less. Also, by increasing of $0.75 \%$ composite fiber in a high performance concrete there is increase of cube compressive strength to $12.25 \%$ over the $0.25 \%$ of composite fiber $(\mathrm{ppf}=0.25 \%)$ and $0 \%$ of mineral admixtures. It is clear that the strength increase with increase of percentage of fibers

Table-1: Cube Compressive strength

\begin{tabular}{|c|c|c|c|c|}
\hline \multirow{2}{*}{$\begin{array}{c}\text { Sl. } \\
\text { No }\end{array}$} & Total \% of & \multicolumn{3}{|c|}{ Cube Compressive strength (MPa) } \\
\cline { 3 - 5 } & fibres & \multicolumn{2}{|c|}{$0 \%$ mineral admixtures w/c Ratio } \\
\cline { 3 - 5 } & 0.30 & 0.35 & 0.40 \\
\hline 1 & 0.25 & 49.85 & 48.92 & 47.51 \\
\hline 2 & 0.75 & 54.86 & 53.06 & 51.25 \\
\hline
\end{tabular}

Table-2: Cube Compressive strength

\begin{tabular}{|c|c|c|c|c|}
\hline \multirow{2}{*}{$\begin{array}{c}\text { S1. } \\
\text { No }\end{array}$} & \multirow{2}{*}{$\begin{array}{c}\text { Total \% of } \\
\text { composite } \\
\end{array}$} & \multicolumn{3}{|c|}{ Cube Compressive strength (MPa) } \\
\cline { 3 - 5 } & $22.5 \%$ mineral admixtures w/c Ratio \\
\cline { 3 - 5 } & 0.30 & 0.35 & 0.40 \\
\hline 1 & 0.25 & 50.85 & 49.85 & 48.60 \\
\hline 2 & 0.75 & 55.96 & 54.07 & 52.41 \\
\hline
\end{tabular}

Table-3: Cube Compressive strength

\begin{tabular}{|c|c|c|c|c|}
\hline \multirow{2}{*}{ S1. } & \multirow{2}{*}{$\begin{array}{c}\text { Total \% of } \\
\text { No }\end{array}$} & \multicolumn{3}{|c|}{ Cube Compressive strength (MPa) } \\
\cline { 3 - 5 } & fibres & $37.5 \%$ mineral admixtures w/c Ratio \\
\cline { 3 - 5 } & 0.30 & 0.35 & 0.40 \\
\hline 1 & 0.25 & 46.01 & 44.45 & 43.17 \\
\hline 2 & 0.75 & 50.02 & 48.12 & 46.61 \\
\hline
\end{tabular}

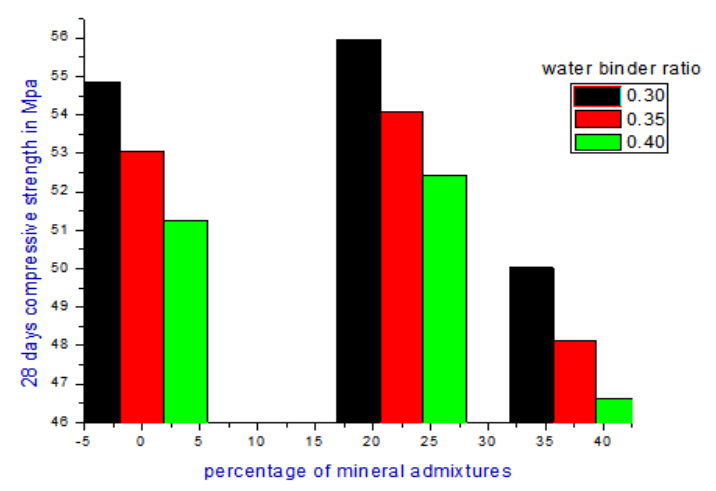

Chart -1: Variations of 28 days compressive strength on different percentage of mineral admixtures 


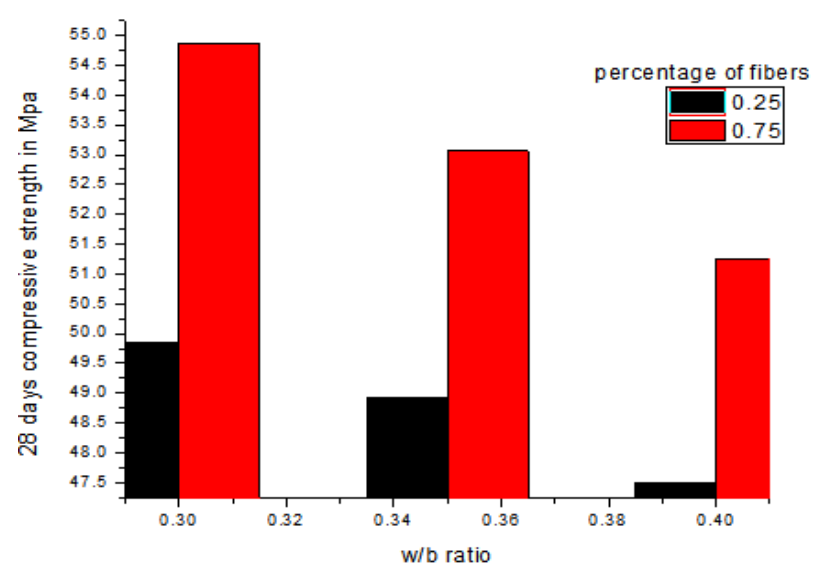

Chart -2: 28 days compressive strength v/s different water binder ratio with variations of composite fibers.

Split tensile strength test: It is observed that from table, the cylinder tensile strength is increased by $2.24 \%$ than the $0 \%$ of mineral admixtures split tensile strength. Also , by increasing of $0.75 \%$ composite fiber in a high performance concrete there is increase of tensile strength to $8.53 \%$ over the $0.25 \%$ of composite fiber $(\mathrm{ppf}=0.25 \%)$ and $0 \%$ of mineral admixtures. It is clear that the strength increases with increase of $\%$ of composite fiber.

Table-4: Split tensile strength

\begin{tabular}{|c|c|c|c|c|}
\hline \multirow{2}{*}{$\begin{array}{c}\text { S1. } \\
\text { No }\end{array}$} & Total \% of & \multicolumn{3}{|c|}{ Split Tensile strength in (MPa) } \\
\cline { 3 - 5 } & fibres & 0.30 & 0.35 & 0.40 \\
\cline { 3 - 5 } & & $0 \%$ mineral admixturesw/c Ratio \\
\hline 1 & 0.25 & 4.86 & 4.65 & 4.58 \\
\hline 2 & 0.75 & 5.14 & 4.88 & 4.77 \\
\hline
\end{tabular}

Table-5: Split tensile strength

\begin{tabular}{|c|c|c|c|c|}
\hline \multirow{2}{*}{$\begin{array}{c}\text { S1. } \\
\text { No }\end{array}$} & \multirow{2}{*}{$\begin{array}{c}\text { Total \% of } \\
\text { composite } \\
\text { fibres }\end{array}$} & \multicolumn{3}{|c|}{ Split Tensile strength in (MPa) } \\
\cline { 3 - 5 } & & 0.30 & 0.35 & 0.40 \\
\hline 1 & 0.25 & 4.96 & 4.74 & 4.68 \\
\hline 2 & 0.75 & 5.23 & 4.98 & 4.88 \\
\hline
\end{tabular}

Table-6: Split tensile strength

\begin{tabular}{|c|c|c|c|c|}
\hline \multirow{2}{*}{$\begin{array}{c}\text { S1. } \\
\text { No }\end{array}$} & \multirow{2}{*}{$\begin{array}{c}\text { Total \% of } \\
\text { composite } \\
\text { fibres }\end{array}$} & \multicolumn{3}{|c|}{ Split Tensile strength in (MPa) } \\
\cline { 3 - 5 } & & 0.30 & 0.35 & 0.40 \\
\hline 1 & 0.25 & 4.38 & 4.27 & 4.15 \\
\hline 2 & 0.75 & 4.64 & 4.50 & 4.33 \\
\hline
\end{tabular}

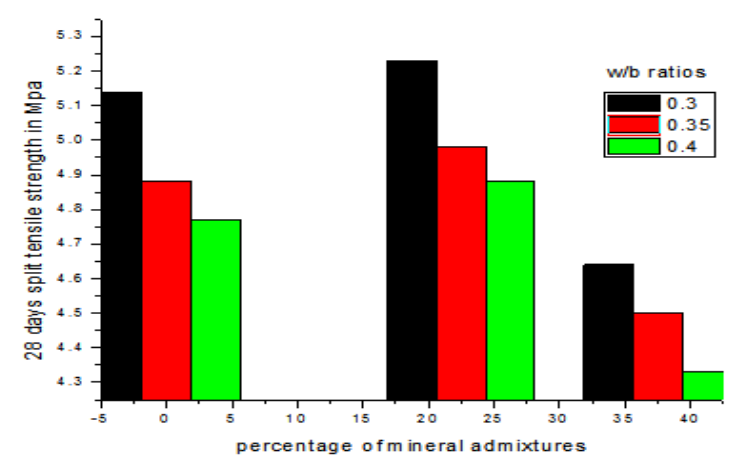

Chart -3: Variations of 28 days split tensile strength on different percentage of mineral admixtures

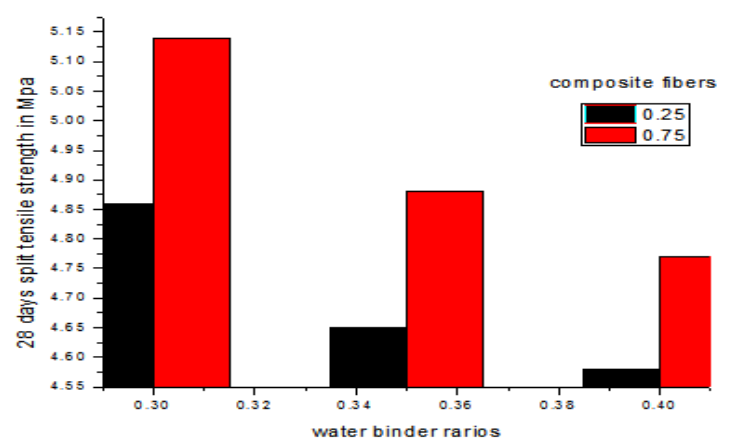

Chart -4: 28 days split tensile strength v/s different water binder ratio with variations of composite fibers

Flexural strength test: It is observed that from above table 4 the flexural strength is increased by $2.12 \%$ than the $0 \%$ of mineral admixtures flexural strength. Also by increasing of $0.75 \%$ composite fiber in a high performance concrete there is increase of flexural strength to $6.02 \%$ over the $0.25 \%$ of composite fiber $(\mathrm{ppf}=0.25 \%)$ and $0 \%$ of mineral admixtures. It is clear that the strength increases with increase of percentage of fibers.

Table -7: Flexural strength

\begin{tabular}{|c|c|c|c|c|}
\hline \multirow{2}{*}{ Sl. } & \multirow{2}{*}{$\begin{array}{c}\text { Total \% of } \\
\text { No }\end{array}$} & \multicolumn{3}{|c|}{ Flexural strength in $(\mathrm{MPa})$} \\
\cline { 3 - 5 } & fibres & 0.30 & 0.35 & 0.40 \\
\cline { 3 - 5 } & 0.25 & 5.68 & 5.35 & 5.18 \\
\hline 1 & 0.75 & 5.86 & 5.68 & 5.38 \\
\hline 2 & & \multicolumn{4}{|c|}{} \\
\hline
\end{tabular}

Table -8: Flexural strength

\begin{tabular}{|c|c|c|c|c|}
\hline \multirow{2}{*}{ Sl. } & Total \% of & \multicolumn{3}{|c|}{ Flexural strength in $(\mathrm{MPa})$} \\
\cline { 3 - 5 } No & composite & $22.5 \%$ mineral admixtures w/c Ratio \\
\cline { 3 - 5 } & fibres & 0.30 & 0.35 & 0.40 \\
\hline 1 & 0.25 & 5.81 & 5.46 & 5.28 \\
\hline 2 & 0.75 & 5.98 & 5.79 & 5.49 \\
\hline
\end{tabular}

Table -9: Flexural strength

\begin{tabular}{|c|c|c|c|c|}
\hline \multirow{2}{*}{ Sl. } & Total \% of & \multicolumn{3}{|c|}{ Flexural strength in (MPa) } \\
\cline { 3 - 5 } No & composite & & $37.5 \%$ & mineral admixturesw/c Ratio \\
\cline { 3 - 5 } & fibres & 0.30 & 0.35 & 0.40 \\
\hline 1 & 0.25 & 5.20 & 4.92 & 4.73 \\
\hline 2 & 0.75 & 5.36 & 5.14 & 4.92 \\
\hline
\end{tabular}




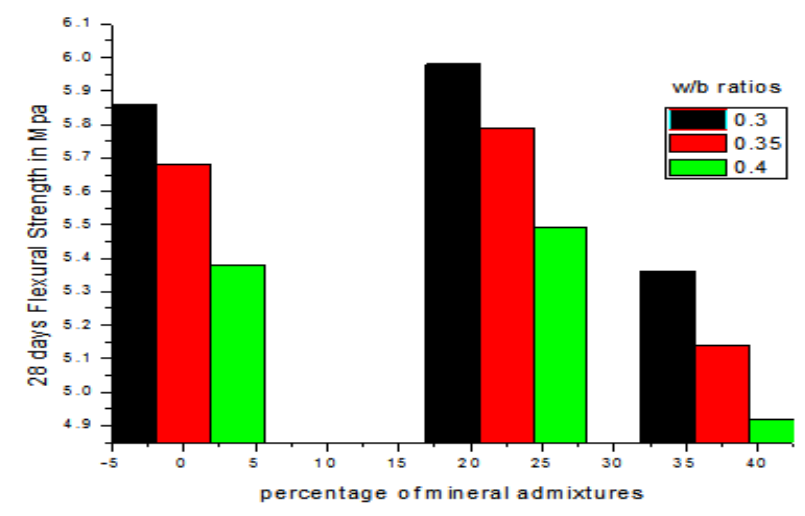

Chart -5: Variations of 28 days compressive strength on different percentage of mineral admixtures.

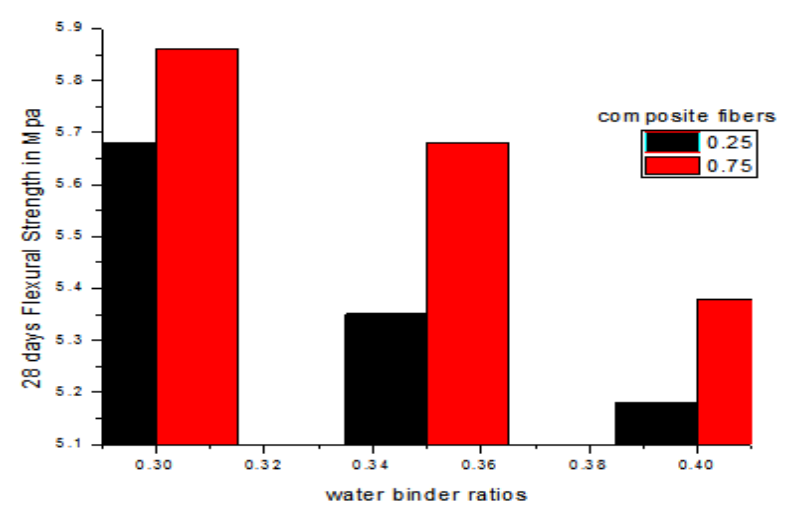

Chart -6: 28 days flexural strength v/s different water binder ratio with variations of composite fibers.

\section{CONCLUSIONS}

1. The cement can be replaced by $22.5 \%$ (i.e. $7.5 \%$ of each silica fume, metakaoline and fly ash) of mineral admixtures and matrix has achieved maximum compressive strength, split tensile strength and flexural strength at 7 and 28 days.

2 . The increase in percentage of composite fibers (steel and polypropylene fiber) also increases the compressive strength, split tensile strength and flexural strength at 7 and 28 days.

3. The rise in water binder magnitude relation, decreases the compressive strength, split strength and flexural strength at seven and twenty eight days.

4. Replacing cement by $37.5 \%$ of mineral admixtures ( $12.5 \%$ of each silica fume, metakaoline and fly ash), the 7 and 28 days compressive strength, split tensile strength and flexural strength decreases. It is observed that values are lesser than values obtained at $0 \%$ replacement of cement.

5. It is concluded that, replacing cement by $22.5 \%$ with mineral admixtures $(7.5 \%$ of each silica fume, metakaoline and fly ash) and composite fibers (steel and polypropylene fiber) by $0.75 \%$, the maximum compressive strength, split tensile strength and flexural strength at 7 and 28 days are observed.

\section{REFERENCES}

[1]. Ch. Kusuma Keerthi1, K. Rajasekhar2 Department of Civil Engineering, Siddartha Educational Academy Group of Institution/Integrated Campus , Tirupati, (Rural) Jntua, Anathapuramu, (India) STUDY OF HIGH PERFORMANCE CONCRETE BY USING ADMIXTURES International Journal of Advanced Technology in Engineering and Science vol. No.3, Issue 07, july 2015. www.ijates.com

[2]. Dr. B. Vidivelli1, A. Jayaranjini2 1, 2 (Professor, Research Scholar, Department of Structural Engineering, Annamalai University, Annamalai Nagar, Tamil Nadu.) Comparative Study on High Performance Concrete with Different Admixtures International journal Of Modern Engineering Research (IJMER)

[3]. Magudeaswaran.P, Eswaramoorthi. P, "Experimental Investigation of Mechanical properties on Silica fume and Fly ash as Partial Cement Replacement of High Performance Concrete," IOSR Journal of Mechanical and Civil Engineering (IOSR-JMCE) Volume 6,Issue 4 (May.Jun. 2013), pp57-63.

[4]. Arfath Khan Md1, Abdul Wahab2, B. Dean Kumar3 1Asst Prof, CED, NITS, 2Asst Prof, CED, NSAKCET, 3 Assoc Prof, CED, JNTUHCEH “ Study of Strength Properties of Fibrous Concrete Using Metakaolin and Condensed Silica Fume"

[5]. International Journal of Emerging Technology and Advanced Engineering Website: www.ijetae.com (ISSN 2250-2459, ISO 9001:2008 Certified Journal, Volume 3, Issue 5, May 2013)

\section{BIOGRAPHIES}

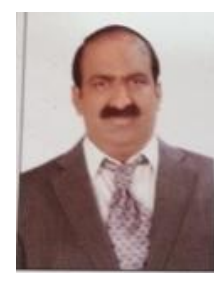

Dr.H.M.Somasekharaiah holds his Ph.Ddegree from JNTU, Ananthapura, India. Professor in Department of Civil Engineering at RYMECBallari, Karnataka, India. He is having 27 years of academic teaching, consultancy and research experience. . He has published many international and national journals. He has supervised many $\mathrm{PhD}$ and M.Tech projects.

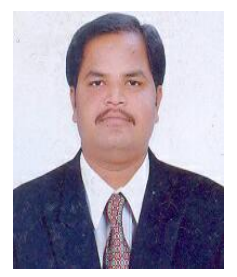

Mahesh Sajjan received his BE in Civil Engineering, M.Tech in Structural Engineering and is currently pursuing his Ph.D (VTU, Belagavi) in Hybrid fiber reinforced concrete with mineral admixtures. He is an Assistant Professor in Department of Civil Engineering at RYMECBallari, Karnataka, India

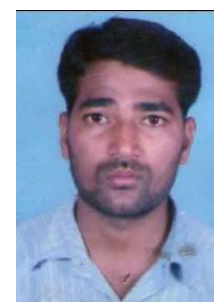

Nelson Mandela. received his BE in Civil Engineering, pursuing his M.Tech in Structural Engineering atRYMECBallari, Karnataka, India. 